\title{
Efficacy of Different Fungicides and Bio Control Agents Against Fusarium oxysporum, Causal Agent of Potato Dry Rot
}

\author{
Shehbaz Jawed', Hua-Feng Wang², Xia-Lan Cheng ${ }^{2}$, Anum Mehmood ${ }^{2}$, Arif Hussain Kaleri', \\ Zaheer Ahmed Jatoi ${ }^{2}$, Asif Ali Kaleri ${ }^{3}$, Aftab Ali Kubar ${ }^{2}$ and Mir Muhammad Nizamani ${ }^{2 *}$ \\ 'Department of Plant Pathology Faculty of Crop Protection, Sindh Agriculture University Tando Jam, \\ Pakistan; shahbazjawed18@gmail.com \\ ${ }^{2}$ Hainan Key Laboratory for Sustainable Utilization of Tropical Bioresources, Institute of Tropical Agriculture \\ and Forestry, Hainan University, Haikou, China; wanghuafeng2012@foxmail.com, chengxialan@qq.com, \\ gooddranam@yahoo.com, hussainarifkaleri@outlook.com, jatoizaheer@gmail.com, kubar.aftabali@gmail.com, \\ mirmohammadnizamani@outlook.com \\ ${ }^{3}$ Department of Agronomy Faculty of Crop Protection, Sindh Agriculture University Tando Jam, \\ Pakistan; asifalikaleri2013@gmail.com
}

\begin{abstract}
Objectives: To study the prevalence of potato dry rot in different vegetables markets. To evaluate the effect of Fusarium oxysporum on potato. To study the efficacy of different antagonistic agents and fungicides against mycelia growth of $F$. oxysporum. Methods/Statistical Analysis: Survey was done from different vegetable markets of Pakistan. Potatoes showing dry rot symptoms were collected and brought to Plant Pathology laboratory. Findings: Antagonistic organisms cause highly significant inhibition in the growth of $F$. oxysporum which was higher than $60 \%$. Lowest growth of $F$. oxysporum was found because of an interaction of P. varioti $(15.5 \mathrm{~mm})$ and Paecilomyces lilacinus $(16.75 \mathrm{~mm})$. Both them cause $82.39 \%$ and $80.96 \%$ inhibition in the growth of targeted pathogen respectively. Whereas in case of interaction with T. harzianum and Trichoderma polysporum the growth of $F$. oxysporum was $22.00 \mathrm{~mm}$ and $27.75 \mathrm{~mm}$, which is still significantly low as compared to the growth of $F$ oxysporum $88.00 \mathrm{~mm}$ in separate control plates. The growth of pathogen was inhibited by Paecilomyces spp. and mutual inhibition of both antagonist and pathogen at few $\mathrm{mm}$ was observed. Whereas, in the case of Trichoderma spp. pathogen and antagonist produce intermingled growth, the growth of the F. oxysporum was ceased and overgrown by antagonist. In-vitro amendment of fungicide in culture media inhibits the colony growth of $F$. oxysporum. Reduction in colony diameter of $F$. oxysporum was observed with the application of used antagonistic fungi. Application/ Improvements: These results can be used in the analysis and bio-control methods of Potato dry rot.
\end{abstract}

Keywords: Bio-Control, Dry Rot, Fungicides, Fusarium oxysporum, Potato

\section{Introduction}

Potato (Solanum tuberosum L.) belongs to the family solanaceae that includes other 2000 plant species. Tomato (Lycopersicum esculentum L.), sweet pepper (Capsicum annuum L.), eggplant (Solanum melongena var. esculentum L.), tobacco (Nicotiana tabacum L.), and petunia (Petunia hybrid L.) also belongs to this family. Potato ranks fourth after wheat, rice and maize in the list of most important staple crop of the world.

It is a good source of iron while their vitamin $\mathrm{C}$ contents help in iron absorption. Its consumption is increasing because it is not only cheap but also a rich source of carbohydrates, starch and contributed a lot in the reduction of food shortage globally ${ }^{1}$. 
The losses caused by diseases and insects constitute the major constraints that faced by the potato growers worldwide. Apart from the field diseases, postharvest diseases caused considerable economic losses in the quality and quantity of the produced during transport, storage and marketing ${ }^{2}$. Among the diseases the most important wide spread and important caused by pathogenic fungi, affecting tubers and vegetative parts ${ }^{3}$. A number of field and storage disease of potatoes that reduces the quantity and market value are Black scurf ${ }^{4}$, Late blight (Phytophthora infestans) ${ }^{5}$, Early blight (Alternaria solani) ${ }^{6}$, Powdery scab (Spongospora subterrannea) ${ }^{7}$, Wilt disease (Verticillium albo-atrum) $^{8}$, Fusarium dry rot (Fusarium spp.), Silver scurf (Helminthosporium solani), Gangerene (Phoma exigua $)^{9}$, Pink rot (Phytophthora erythroseptica) and Watery wound rot (Pythium ultimum and P. debaryanum $)^{10}$.

One of the main fungal diseases that attack potato is Fusarium dry rot. This problem persists throughout the world. There are many species of Fusarium reported to cause dry rot of potato worldwide ${ }^{3}$. Fusarium dry rot caused by many Fusarium species like $F$. coeruleum, F. eumartii, F. oxysporum, F. sulphureum and F. sambucinum $^{11}$. It has been estimated that dry rot caused by Fusarium spp. caused 6 to $25 \%$ yield losses ${ }^{12}$. Adding to this yield loss, Fusarium spp. are also well known for the toxins production in attacked host and responsible for mycotoxicoses of humans and animals ${ }^{13,14}$. One of the toxins produced by the Fusarium spp. which because dry rots is trichothecene. This toxin is a serious inhibitor of protein synthesis in prokaryote and can cause serious health troubles ${ }^{15}$.

In Turkey, four Fusarium spp. namely F. sambucinum, F. solani, F. culmorum and F. oxysporum are found to be common causes of dry rot of potatoes and have the potential for complete destruction of potatoes in storage ${ }^{2}$. Eighteen percent of tubers arriving at New York markets from 1972-1980 showed symptoms of Fusarium dry $\operatorname{rot}^{16}$. While as high as $60 \%$ of graded tubers in Scotland was affected by dry $\operatorname{rot}^{17}$.

Symptoms of Fusarium dry rot include minute brown areas on the surface of tubers ${ }^{18,19}$, the infected tubers appear wrinkled and rolled tissues from the surface, and rot also creates depressions/ cavity in the surface of the tuber. These affected tissues turn brown, grey or black. When symptoms advances spore masses of blue, white, yellow, purple, black or pink colour may also observe. Seed tubers and potatoes for consumption may not com- pletely. Storage tuber mummifies and ultimately only the dry shell persists ${ }^{20,21}$. Mode of spread is by planting infected tubers or by contaminated soil, as the pathogen is soil borne, airborne or carried in plant residue ${ }^{22}$.

Biological control of dry rot of potato using different antagonists only evaluated for experimental purposes ${ }^{23}$. Antagonistic organisms like Trichoderma spp. and Pseudomonas aeruginosa have been found to be effective management strategy ${ }^{24}$.

Fungicide like Maxim MZ, Tops MZ, and Moncoat MZ may be used for the efficient control of potato dry rot. Many chemicals, including Thiabendazole, may be applied to seed tubers before sowing ${ }^{25}$. Continuous use of same fungicide is the main factor to develop resistance for it as documented in potato dry rot pathogen against Thiabendazole ${ }^{11}$.

Indiscriminate use of chemical pesticides to control various pests and pathogenic microorganisms of crops plants is causing health hazard both in terrestrial and aquatic lives through their residual toxicity ${ }^{26}$. Much attention is being focused on the alternative methods of pest control ${ }^{27}$.

Keeping in view the importance of potato dry rot recent studies carried out to determine the prevalence of potato dry rot at study area and to evaluate the efficacy of different antagonistic agents and fungicides against $F$. oxysporum causal agent of dry rot of potato.

\section{Materials and Methods}

\subsection{Survey and Sampling of Diseased Specimen}

Survey was done from different vegetable markets of Hyderabad region. Potatoes showing dry rot symptoms were collected and brought to Plant Pathology laboratory. Incidence of dry rot of potatoes was also recorded with help of following formula:

$$
\text { Incidence }(\%)=\frac{\text { Number of potatoes with dry rot }}{\text { Total number of potatoes observed }} \times 100
$$

\subsection{Isolation and Identification of Causal Fungus}

The isolation and identification of fungi was carried out as described by $^{2}$ as follows; tubers were washed under running tap water to remove the mud and then air dried. A 6 
$\mathrm{mm}$ diameter and $5 \mathrm{~mm}$ deep pieces were excised with a cork borer from the affected area of each tuber. The tubers sections were surface sterilized in 5\% commercial bleach solution for $1 \mathrm{~min}$. Tuber sections were dried on sterilized paper and plated on Potato Dextrose Agar (PDA). After 5 days of incubation at room temperature under natural light, predominantly isolated fungal colonies developing from the plant material were identified by microscopic observations with the help of literature.

Pure culture of fungus was maintained by periodical transfer on PDA plates. Small colony from corner of the fungal growth was picked up with help of inoculation needle and placed on the surface of new freshly prepared PDA plates. Only one disc transferred per PDA plate and incubated at $25^{\circ} \mathrm{C}$ resulting pure culture were multiplied periodically on new media throughout the study.

\subsection{Pathogenicity Test of Causal Pathogen}

Pathogenicity test of causal pathogen was carried out for the confirmation of disease-causing fungus under in-vitro conditions to prove the Koch's postulates. The procedure was performed according to Peters ${ }^{28}$. The healthy potato tubers of variety "Diamond" were used in this experiment. Tubers appearing uniform in size (100-120 g) were selected for this test. First tubers were washed to remove the surface soil and sterilized by dipping them in $80 \%$ solution of ethanol and then air dried. Then the tubers wounded with a cork borer with a diameter of $5 \mathrm{~mm}$ to a depth of $5 \mathrm{~mm}^{28,29}$. An agar plug (5 $\mathrm{mm}$ diameter) containing active growth of $F$. oxysporum isolates cut from the margin of a 3-day-old cultures grown on PDA and placed into the wound, which was subsequently sealed with the excised plug of tuber tissue. All the wounded potato tubers were wrapped in polyethylene bags and incubated in the dark at $20^{\circ} \mathrm{C}$ for 3 weeks. As a control, tubers were wounded with the help of cork borer like it's done in treatment then inoculated with only an agar plug without fungus. After three weeks data were recorded on the basis of symptoms development and lesion area were measured in $\mathrm{cm}$ with the help of scale.

\subsection{Evaluation of Different Bio-Control Agents}

Different biocontrol agents were obtained From Agriculture Research Institute, Tandojam to evaluate against Fusarium dry rot of potato by dual culture method. Briefly PDA plates were prepared and inoculated by F. oxysporum and selected biocontrol agent aseptically. Both of them were placed at the periphery of Petri plate at equidistance of 2 to $3 \mathrm{~cm}$ in opposite direction. Petri plates inoculated with pathogen only served as control. All the plates were incubated at $25^{\circ} \mathrm{C}$ in incubators. Plates were observed regularly and data on colony growth in $\mathrm{cm}$ were recorded with the help of scale and antagonistic nature of the bio agent was recorded. Resulting data on colony diameter was calculated for percent inhibition over control with the help of formula given below:

$$
\text { Inhibition }(\%)=\frac{C-T}{C} \times 100
$$

Whereas, $\mathrm{C}=$ Growth of pathogen in control plates; $\mathrm{T}=$ Growth of pathogen in dual culture plates.

After prolonged storage interactions were assessed using a key based on observations of Dickinson and Boardman $^{30}$ as given below:

A. Mutually intermingling growth where both fungi grew into one another without any microscopic signs of interaction.

Bi. Intermingling growth where the fungus being observed was growing into the opposed fungus either above or below its colony.

Bii. Intermingling growth where the fungus under observation has ceased growth and is overgrown by another colony.

C. Slight inhibition where the fungus approach each other until almost in contact and a narrow demarcation line, 0.1-2 $\mathrm{mm}$, between the two colonies clearly visible.

D. Mutual inhibition at a distance of $>2 \mathrm{~mm}$.

\subsection{Efficacy of Different Fungicides}

The efficacy of different fungicides for controlling F. oxysporum responsible for postharvest infection was carried out with ten different fungicides. For this purpose, Carbendzim, Topsin-M, Mancozeb, Antracol, Gemstar, Scholar, Nativo, Tilt, Score and Radomil were selected and evaluated with four different doses, i.e., $1 \mathrm{ppm}, 10$ ppm, 100 ppm, 1000 ppm by food poisoning method under in-vitro conditions. The details of fungicides with their company name, active ingredients and brand name are given in Table 1. 
Table 1. List of the fungicides used in the experiments

\begin{tabular}{|l|l|l|}
\hline Brand Name & Company Name & Active ingredient \\
\hline Topsin-M & Arysta & Thiophanate Methyl 70 WP \\
\hline Mancozeb & FMC & Dithiocarbamates 75\% WP \\
\hline Antracol & Bayer & Propineb 70\% WP \\
\hline Carbendazim & Clear & Carbendazim 50 WP \\
\hline Ridomil & Sygenta & Metaxyl 68 WP \\
\hline Score & Sygenta & Difinaconazole 250 EC \\
\hline Tilt & Sygenta & Propiconazole 250 EC \\
\hline Nativo & Bayer & (Tebuconazole+Trifloxystobin)75WG \\
\hline Scholar & Sygenta & Fludioxonil 230 SC \\
\hline Gemstar & Sun Crop & Azoxystrobin 250 EC \\
\hline
\end{tabular}

Concentrations given above were prepared by serial dilution method. The required quantity of fungicide was mixed in the medium after sterilization of media. Medium without fungicide were served as control. Before pouring the media were also amended with streptomycin sulphate at $5 \mathrm{ml} / \mathrm{L}$ and penicillin at $10^{6}$ units/L to avoid bacterial contamination. Media without fungicide served as control. Equal volume of media i.e., about $15 \mathrm{ml}$ were poured in each Petri dish and inoculated in the centre with a $5 \mathrm{~mm}$ disk of $F$. oxysporum after solidification of media. These plates were incubated as and data were recorded as described above. Growth was recorded daily till any of the plate found full of the growth of F. oxysporum. Finally resulting data was calculated for inhibition percent because of fungicide with the help of formula as follows:

$$
\text { Inhibition }(\%)=\frac{C-T}{C} \times 100
$$

Whereas; $\mathrm{C}=$ Colony diameter of pathogen in control plates; $\mathrm{T}=$ Colony diameter of pathogen in plates amended with fungicide (treatment plate).

\section{Results}

\subsection{Prevalence of Potato Dry Rot}

Potatoes showing dry rot symptoms were collected from different markets (Figure 1). Hundred potatoes were randomly examined from each store. The disease found to prevail in $70 \%$ of the stored visited with a very low incidence. Average disease incidences of dry rot of potatoes were recorded $3.4 \%$. The isolation and identification of fungi was carried out by tissue isolation methods. Isolations were made with affected potatoes. Total 100 sections were placed over the surface of PDA medium. After incubation of 5 days at $25^{\circ} \mathrm{C}$ fungal colonies identified by microscopic observations with the help of literature as Fusarium spp. and Aspergillus spp. F. oxysporum was appeared as most predominant fungus with $59 \%$ frequency (Table 2). Pure cultures of F. oxysporum were maintained on PDA medium and were multiplied periodically on new media throughout the study. On PDA medium it produced white aerial mycelia became tinged with light purple. From backside of plates dark purple and produces abounded micro and macro conidia, Microconidia were oval to ellipsoid cylindrical while macroconidia long fusoid to falcate in shape with 3 or 4 septa (Figure 2). These morphological characteristics are similar those described ${ }^{19,31}$.

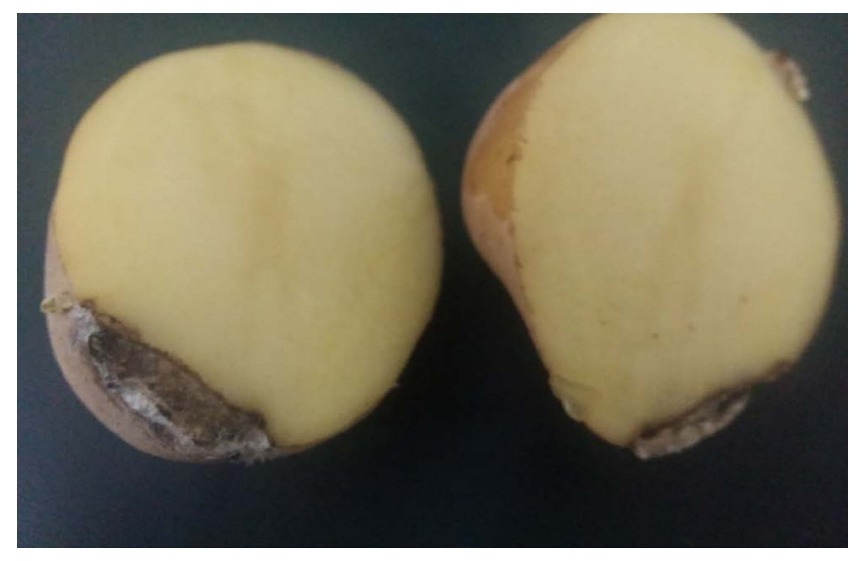

Figure 1. Potato tubers showing dry rot disease symptoms. 

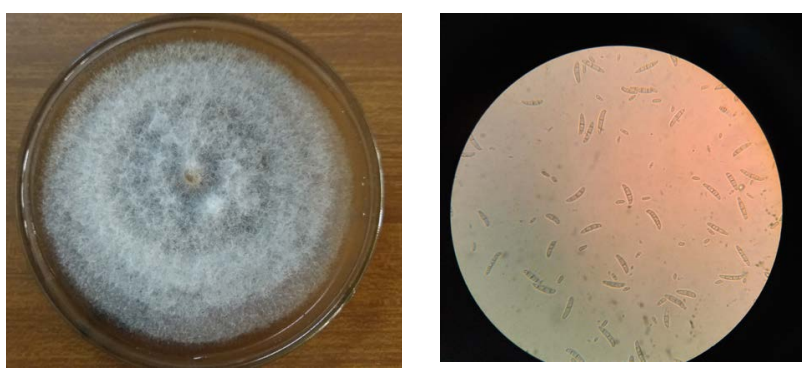

Figure 2. Growth of F. oxysporum isolated from potato tubers having dry rot of potato disease on PDA and macro and micro conidia under 400X magnification of compound microscope.

Table 2. Disease incidences of potato dry rot collected from 10 different vegetables market of Hyderabad regions and frequency of isolated fungi

\begin{tabular}{|l|l|}
\hline \multirow{2}{*}{ Incidences (\%) } & $\begin{array}{l}(34 / 1000) \\
\end{array}$ \\
& $3.4 \%$ \\
\hline \multirow{3}{*}{ Frequency of isolated fungi } & Fusarium oxysporum $(58 \%)$ \\
\cline { 2 - 2 } & Another Fusarium spp. $(30 \%)$ \\
\cline { 2 - 2 } & Aspergillus spp. $(22 \%)$ \\
\hline
\end{tabular}

\subsection{Pathogenicity Test F. oxysporum on Potato Tubers}

Pathogenicity test of $F$. oxysporum was carried out for the confirmation of disease-causing fungus under in-vitro conditions to prove the Koch's postulates. After 3-week incubation, the inoculated potatoes showed wrinkled and rotted symptoms of typical dry rot of potato. The rotted areas of the potatoes were brown, grey, or black and the rot creates depressions in the surface of the tuber. White fungal growth was also apparent on rotted areas. Lesion area after 20 days of inoculation was extended up to $27.10 \mathrm{~mm}$.

Very small lesion were also found to develop in uninoculated control potatoes $(1.8 \mathrm{~mm})$, where tubers were wounded with the help of corn borer like it's done in treatment then inoculated with only an agar plug without fungus (Figure 3 ).

Effect of different fungicides on colony growth of $F . o x y$ sporum:

The efficacy of different fungicides against the colony growth of $F$. oxysporum was checked under laboratory conditions. For this purpose, Radomil, Topsin-M, Antracol, Mancozeb, Carbendzim, Score, Tilt, Scholar, Nativo, and Gemstar, were selected and evaluated with

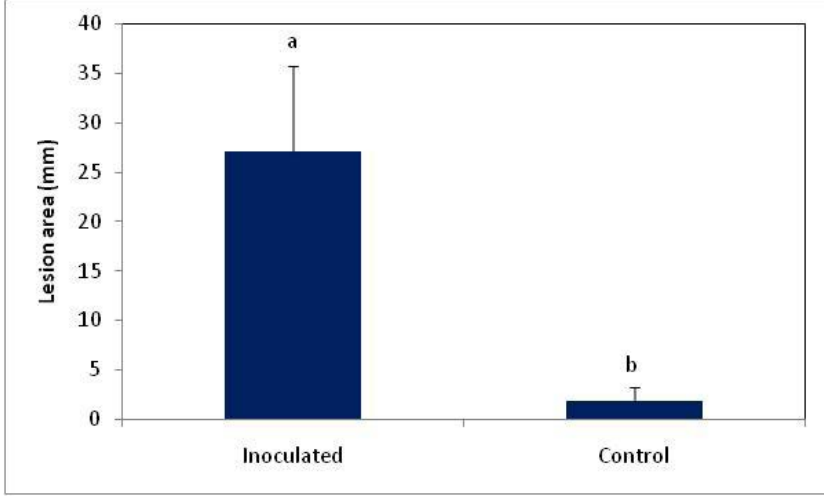

Figure 3. Effect of artificial inoculation of F. oxysporum on lesion development. Data was recorded after 22 days of incubation at $25^{\circ} \mathrm{C}$.

five different doses, i.e., 1, 10, 100, 1000 and $10000 \mathrm{ppm}$ by Food poisoning method. All concentrations of fungicides reduced the growth of $F$. oxysporum as compared to control. However, higher concentrations were more effective than the lower ones. The growth of the test pathogen gradually decreased with increasing concentrations. All the fungicide at $10000 \mathrm{ppm}$ completely stops the growth of test pathogen.

Score $(63.80 \mathrm{~mm})$, followed by Carbendazim $(69.33$ $\mathrm{mm})$, Gemstar $(70.5 \mathrm{~mm})$ and Mancozeb $(70.80 \mathrm{~mm})$ at produces the lowest growth as compare to other fungicides at the same dose. Topsin-M, followed by Scholar and Score at $10 \mathrm{ppm}$ produces $29.16 \mathrm{~mm}, 45.66 \mathrm{~mm}$ and 53.83 $\mathrm{mm}$ respectively, after seven days of incubation at $28^{\circ} \mathrm{C}$ as compared to the $89.66 \mathrm{~mm}$ growth at control. Topsin-M $(9.83 \mathrm{~mm}$ and $2.16 \mathrm{~mm})$ followed by Mancozeb (21.50 $\mathrm{mm}$ and $5.33 \mathrm{~mm})$ and Scholar $(25.00 \mathrm{~mm}$ and $6.00 \mathrm{~mm}$ ) produces lowest growth respectively at 100 and $100 \mathrm{ppm}$ as compare to other fungicide at the same dose (Figure 4).

IC50 values for each fungicide were also calculated. It greatly varied for each fungicide. Lowest IC50 value was found in case of Topsin-M, Scholar, Antracol and Radomil i.e., 8.65 ppm, 16.99 ppm, 36.45 ppm and 46.89 ppm, respectively. Whereas, highest IC50 value was found in Nativo followed by Tilt and Gemstar i.e., 240.36, 206.32 and 109.96, respectively (Figure 5 and 6).

\subsection{Effect of Different Bio-Control Agents on the Growth of F. oxysporum}

Four different bio-control agents i.e. Paecilomyces lilacinus, Trichoderma harzianum, T. polysporum and $P$. varioti were obtained from ARI Tandojam and evaluated against 


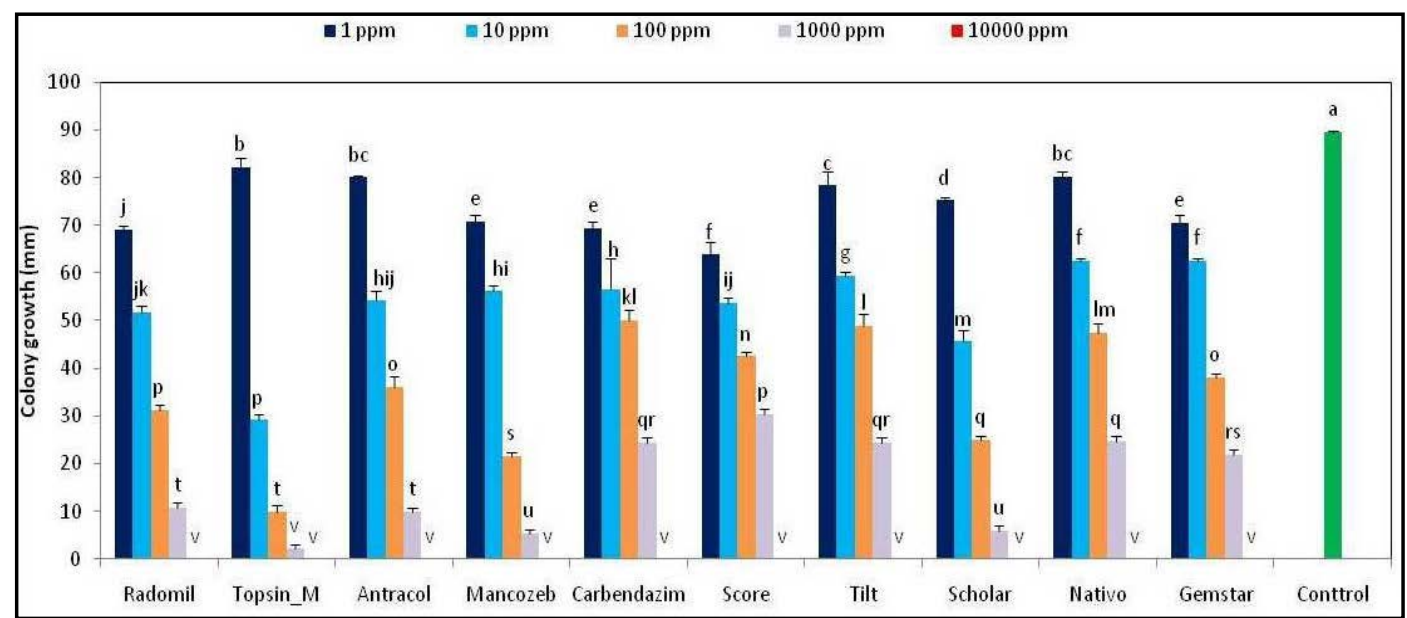

Figure 4. Effect of different concentrations of various fungicides on the colony growth of the F. oxysporum. Bar with different letters show significant difference $(\mathrm{P} \leq 0.05)$ as determined by LSD.
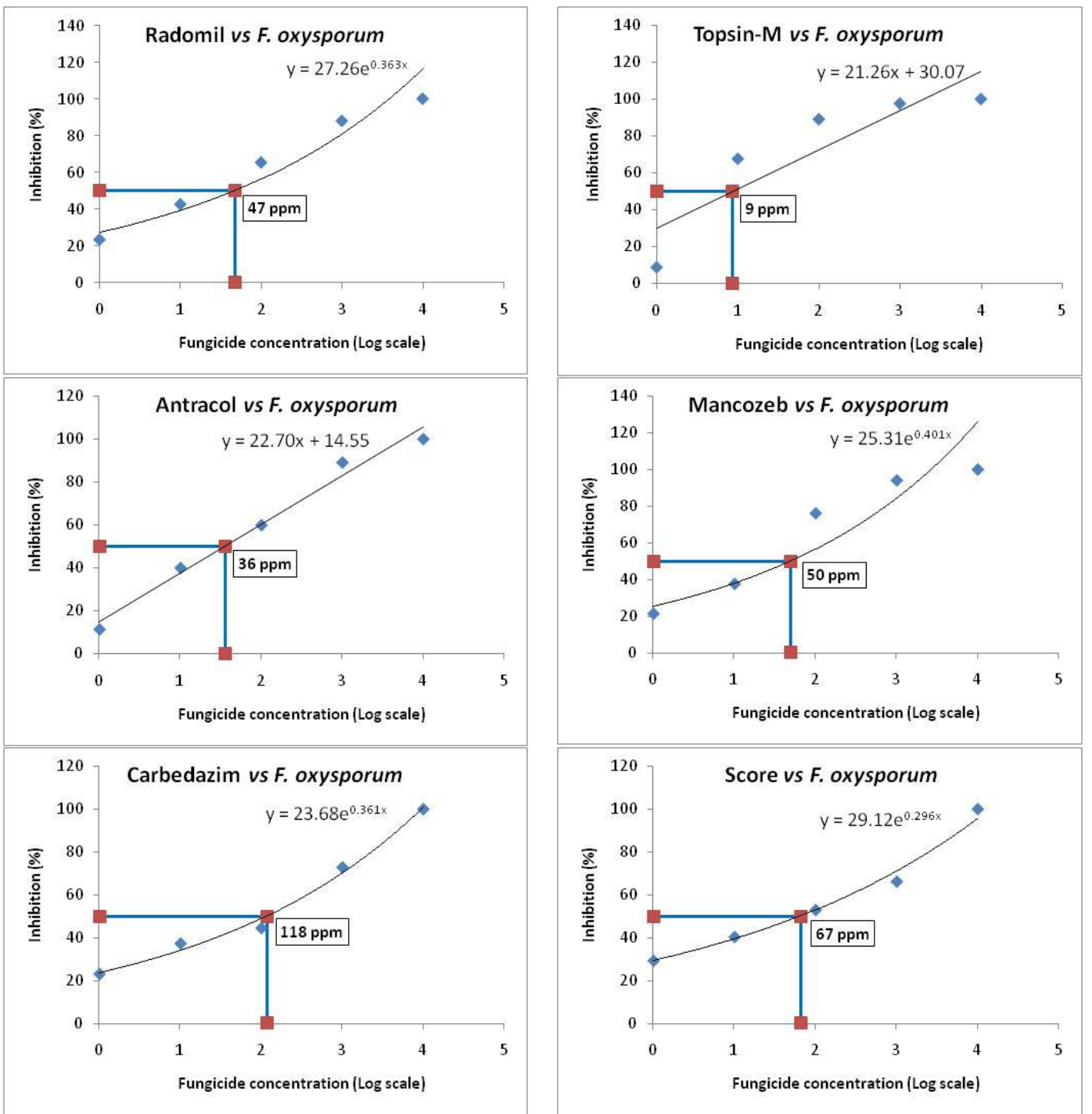

Figure 5. IC50 value of Radomil, Topsin-M, Antracol, Mancozeb, Carbendzim and Score against F. Oxysporum. 

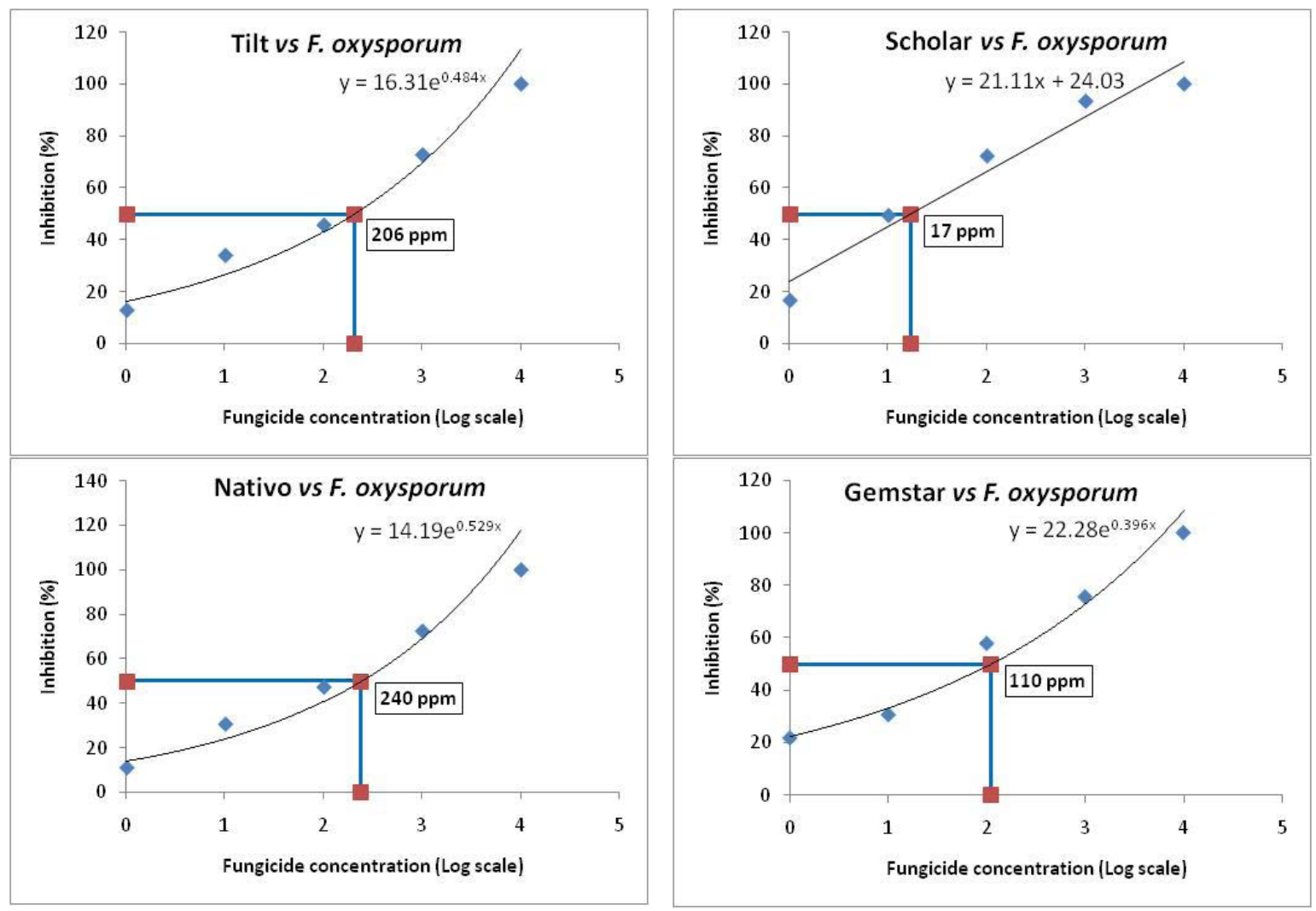

Figure 6. IC50 value of Tilt, Scholar, Nativo and Gemstar against F. Oxysporum.

F. oxysporum by dual culture method. Both of them were placed at the periphery of Petri plate at equidistance in opposite direction. All four antagonistic organisms cause highly significant inhibition in the growth of $F$. oxysporum which was higher than $60 \%$. Lowest growth of $F$. oxysporum was found as a result of interaction of $P$. varioti $(15.5 \mathrm{~mm})$ and P. lilacinus $(16.75 \mathrm{~mm})$. Both of them cause $82.39 \%$ and $80.96 \%$ inhibition in the growth of targeted pathogen, respectively. Whereas in case of interaction with T. harzianum and T. polysporum the growth of F. oxysporum was $22.00 \mathrm{~mm}$ and $27.75 \mathrm{~mm}$, which is still significantly low as compare to the growth of $F$. oxysporum $88.00 \mathrm{~mm}$ in separate control plates. T. harzianum and T. polysporum cause $75.00 \%$ and $68.46 \%$ inhibition in the growth of F. oxysporum (Figure 7). Antagonistic nature of the bio-agents was recorded with prolonged incubation. Both specie Paecilomyces of shows D type interaction i.e. mutual inhibition of both at a distance of few $\mathrm{mm}$ while Trichoderma spp. shows Bii type interaction i.e., $F$. oxysporum and Trichoderma spp. produces intermingled growth; growth of the F. oxysporum was ceased and overgrown by antagonist (Figure 8).

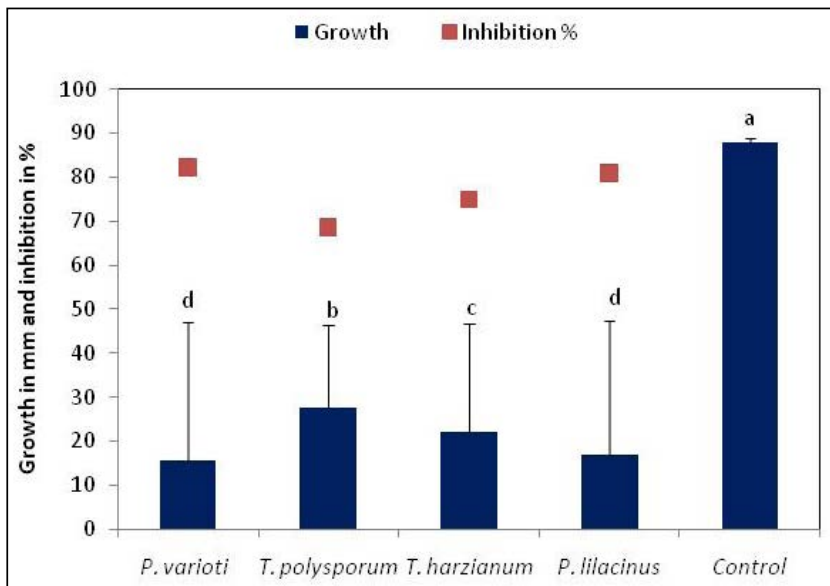

Figure 7. Effect of Paecilomyces varioti, Trichoderma polysporum, T. harzianum and P. lilacinus on the growth/ inhibition of F. oxysporum. Bar with different letters show significant difference $(\mathrm{P} \leq 0.05)$ as determined by LSD.

\section{Discussion}

Dry rot potato is one of the main fungal pathogens that attack potato throughout the world. The disease found to 
A

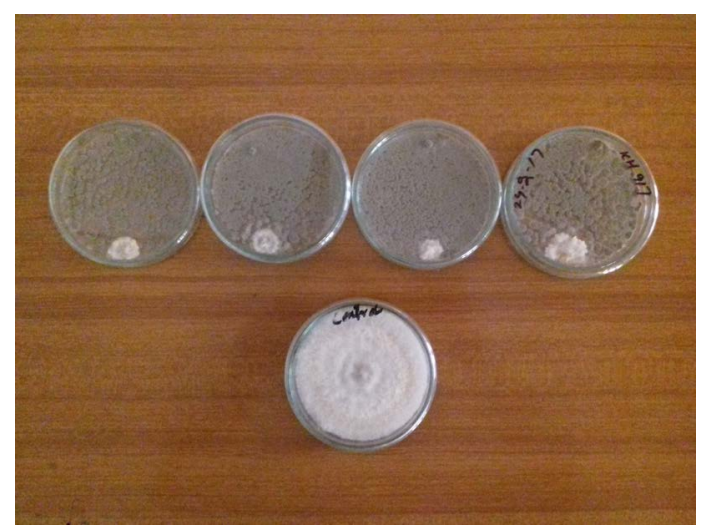

B

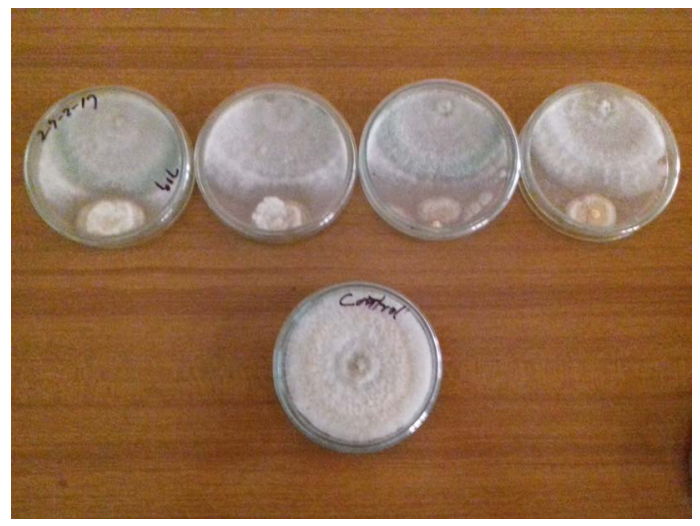

$\mathrm{C}$

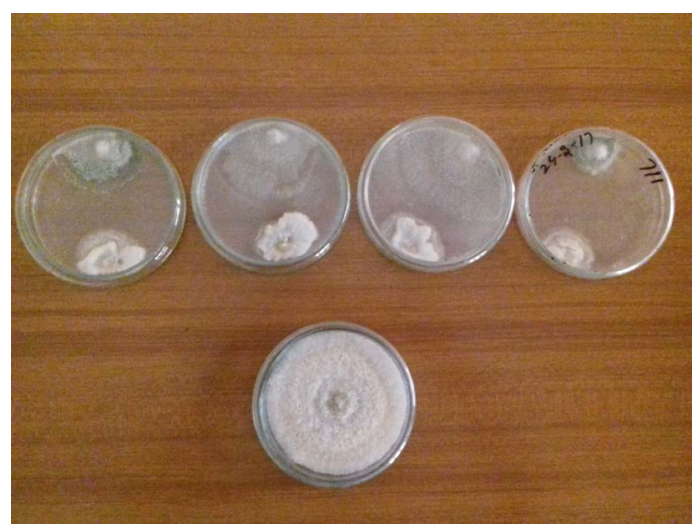

Figure 8. Effect of different biocontrol fungi on the growth/inhibition of $F$. oxysporum $\mathrm{A}=$ Paecilomyces varioti; $\mathrm{B}=$ Trichoderma harzianum and $\mathrm{C}=\mathrm{T}$. Polysporum.

prevail in $70 \%$ of the stored visited in Hyderabad region with a very low incidence. Average disease incidences of dry rot of potatoes were recorded 3.4\%. It has been estimated dry rot caused by Fusarium spp. causes 6\% to 25\% yield losses ${ }^{12}$.

Symptoms of Fusarium dry rot include minute brown areas on the surface of tubers ${ }^{18}$, the infected tubers appear wrinkled and rolled tissues from the surface, and rot also creates depressions/cavity in the surface of the tuber.
These affected tissues turn brown, grey or black. When symptoms advances spore masses of blue, white, yellow, purple, black or pink colour may also observe.

Seed tubers and potatoes for consumption may rot completely. Storage tuber mummifies and ultimately only the dry shell persists ${ }^{14,20,21}$.

The isolation from diseases tissues revealed the association of Fusarium spp. and Aspergillus spp. F. oxysporum was appeared as most predominant fungus. There are many species of Fusarium reported to cause dry rot of potato worldwide ${ }^{3}$. Fusrium dry rot caused by many Fusarium species like F. coeruleum, F. eumartii, F. oxysporum, F. sulphureum and F. sambucinum Fuckel ${ }^{11}$. Mejdoub-Trabelsi ${ }^{24}$ isolated four Fusarium spp. predominantly associated with dry rot of potato. i.e., F. sambucinum, F. oxysporum, F. solani and F. graminearum. On PDA medium it produced morphological characteristic that are similar those described by ${ }^{19,31}$.

Pathogenicity test of $F$. oxysporum confirmed the virulent nature of the pathogen and produces the similar symptoms of potato dry rot. Author in ${ }^{32}$ confirmed the pathogenicity of two F. oxysporum isolates associated with potato dry rot in Colombia. Inoculation with both induced moderate dry rot. Mode of spread is by planting infected tubers or by contaminated, as the pathogen is soil borne, airborne or carried in plant residue ${ }^{22}$. Therefore, emphasis must be given to control dry rot of potato. So far, this disease is managed with the application of fungicides.

Continuous use of same fungicide is the main factor to develop resistance for it as documented in potato dry rot pathogen against Thiabendazole ${ }^{11}$. Therefore, in present study different fungicide determined against $F$. oxysporum causal agent of dry rot of potato. Radomil, Topsin-M, Antracol, Mancozeb, Carbendzim, Score, Tilt, Scholar, Nativo, and Gemstar, were selected and evaluated with five different doses, i.e., 1, 10, 100, 1000 and 10000 ppm by food poisoning method. All concentrations of fungicides reduced the growth of F. oxysporum as compared to control. However, higher concentrations were more effective than the lower ones. The growth of the test pathogen gradually decreased with increasing concentrations. All the fungicide at $10000 \mathrm{ppm}$ completely stops the growth of test pathogen. Similarly, Piwoni ${ }^{33}$ found sixty isolates of $F$. avenaceum and forty isolates of $F$. coeruleum sensitive to used fungicide, while eighty-five isolates of sixty eight percent of $\mathrm{F}$. sulphureum and one isolate of $F$. culmorum were found not sensitive to Thiabendazole. All 
the Fusarium spp. were sensitive to Imazalil and were pathogenic when inoculated into potato tubers. Yasmin ${ }^{34}$ also found Azoxystrobin, Quinoline, Hymexazol and Fludioxonil with inhibitory effect on mycelial growth of F. oxysporum f. sp. tuberosi.

IC50 values for each fungicide were also calculated. It greatly varied for each fungicide. Lowest IC50 value was found in case of Topsin-M, Scholar, Antracol and Radomil. Whereas, highest IC50 value was found in Nativo followed ${ }^{35}$ tested six fungicides; Carbendazim, Benomyl, Prochloraz, Azoxystrobin, Fludioxonil and Bromuconazole, against $F$. oxysporum f. sp. lycopersici with seven different concentrations. Prochloraz and Bromuconazole were the most effective fungicides against the pathogen both in vitro and in vivo, followed by Benomyl and Carbendazim. Fungal radial growth was measured and median effective concentration (EC50) values $(\mu \mathrm{g} / \mathrm{ml})$ determined. Biological controls of dry rot with different bio-control agents such as fungi, bacteria, and yeasts have been reported as effective under experimental conditions $s^{23,36}$. Four different bio-control agent's i.e., Paecilomyces lilacinus, $P$. varioti, Trichoderma harzianum and T. polysporum. All four antagonistic organisms cause highly significant inhibition in the growth of F. oxysporum which was higher than $60 \%$. Antagonistic organisms like Trichoderma spp. and Pseudomonas aeruginosa have been found to be effective management strategy $^{24}$. Author in ${ }^{34}$ found reduction in colony diameter of $F$. oxysporum isolated from potato dry rot by $T$. harzianum, $T$. viride and T. virens.

Antagonistic nature of the bio-agents was recorded with prolonged incubation. Growth of pathogen was inhibited by Paecilomyces spp. and mutual inhibition of both antagonist and pathogen at a distance of few $\mathrm{mm}$ was observed. Whereas in case of Trichoderma spp. pathogen and antagonist produces intermingled growth, growth of the F. oxysporum was ceased and overgrown by antagonist. Similar interaction was also reported ${ }^{37}$. Author in ${ }^{34}$ evaluated different Trichoderma spp. against F. oxysporum isolate from potato dry rot i.e., T. harzianum, T. viride and $T$. virens and studied interaction mechanisms which include disintegration of host cytoplasm and/or alteration into cords and/or coiling around pathogen hyphae.

\section{Summary}

Dry rot is considered the most important post-harvest disease that attack potato throughout the world especially for seed production where are store for prolonged duration. The disease found to prevail in $70 \%$ of the stored visited in Hyderabad region with very low incidences. Average disease incidences of dry rot of potatoes were recorded 3.4\%. Symptoms of Fusarium dry rot include minute brown areas on the surface of tubers. The infected tubers appear wrinkled and rolled tissues from the surface, rot also creates depressions/ cavity in the surface of the tuber. These affected tissues turn brown, grey or black. When symptoms advance fungal spore masses of varying colour may also observed. The isolation from diseases tissues revealed the association of Fusarium spp. and Aspergillus spp. F. oxysporum was appeared as most predominant fungus. Pathogenicity test of $F$. oxysporum confirmed the virulent nature of the pathogen and produces the similar symptoms of potato dry rot.

So far, this disease is managed with the application of fungicides. Continuous use of same fungicide is the main factor to develop resistance for it as documented in potato dry rot pathogen against Thiabendazole. In present study, different fungicides were tested against causal agent of dry rot of potato. Ten fungicide i.e., Radomil, Topsin-M, Antracol, Mancozeb, Carbendzim, Score, Tilt, Scholar, Nativo, and Gemstar, were evaluated against F. oxysporum with five different doses, i.e., 1, 10, 100, 1000 and 10000 ppm by food poisoning method. All concentrations of fungicides reduced the growth of F. oxysporum as compared to control. However, higher concentrations were more effective than the lower ones. The growth of the test pathogen gradually decreased with increasing concentrations. All the fungicide at $10000 \mathrm{ppm}$ completely stops the growth of test pathogen. IC50 value for each fungicide was also calculated from fungal radial growth at five different concentrations. It greatly varied for each fungicide. Lowest IC50 value was found in case of Topsin-M, Scholar, Antracol and Radomil. Whereas, highest IC50 value was found in Nativo followed.

Four different bio-control agents' i.e., Paecilomyces lilacinus, $P$. varioti, Trichoderma harzianum and T. polysporum. All four antagonistic organisms cause highly significant inhibition in the growth of $F$. oxysporum which was higher than sixty percent. Antagonistic nature of the bio-agents was recorded with prolonged incubation. Growth of pathogen was inhibited by Paecilomyces spp. and mutual inhibition of both antagonist and pathogen at a distance of few $\mathrm{mm}$ was observed. Whereas in case of Trichoderma spp. pathogen and antagonist produces 
intermingled growth, growth of the F. oxysporum was ceased and overgrown by antagonist.

\section{Conclusions}

Prevalence of potato dry rot in Hyderabad, Sindh, efficacy of different antagonistic agents and fungicides against $F$. oxysporum causal agent of dry rot of potato are studied. Different Fusarium spp. and Aspergillus spp. were found associated with the collected potatoes with varying frequencies. F. oxysporum was appeared as most predominant isolated fungus with the maximum frequency of $59 \%$. Typical symptoms of dry rot of potato appeared on artificially inoculated tubers with F. oxysporum. Fungal fruiting bodies also appeared on rotted areas after prolonged storage.

In vitro fungal growth test in the presence of different fungicide were performed in order to find out best fungicide. Ten fungicides viz., Radomil, Topsin-M, Antracol, Mancozeb, Carbendzim, Score, Tilt, Scholar, Nativo and Gemstar were evaluated against F. oxysporum with five different doses, i.e., 1, 10, 100, 1000 and 10000 ppm by food poisoning method. Fungal diameter in the Petri dishes was recorded every day till any of the treatment find full of fugal growth. All concentrations of fungicides reduced the growth of $F$. oxysporum as compared to control. However, higher concentrations were more effective than the lower ones. The growth of the test pathogen gradually decreased with increasing concentrations. All the fungicide at $10000 \mathrm{ppm}$ completely stops the growth of test pathogen.

IC50 value for each fungicide was also calculated from fungal radial growth at five different concentrations, it greatly varied for each fungicide. Lowest IC50 value was found in case of Topsin-M, Scholar, Antracol and Radomil. Whereas, highest IC50 value was found in Nativo followed.

Four different bio-control agents i.e. Paecilomyces lilacinus, $P$. varioti, Trichoderma harzianum and T. polysporum were tested against dry rot pathogen. All four antagonistic organisms cause highly significant inhibition in the growth of $F$. oxysporum which was higher than sixty percent. Growth of pathogen was inhibited by Paecilomyces spp. and mutual inhibition of both antagonist and pathogen at few $\mathrm{mm}$ was observed. Whereas in case of Trichoderma spp. pathogen and antagonist produces intermingled growth, growth of the F. oxysporum was ceased and overgrown by antagonist.

\section{Recommendation}

The results of the present study shows that dry rot of potato prevail in study area but with low incidences. However, to reduce the present incidences and to reduce the further spread management methods should be evaluated. In-vitro amendment of fungicide in culture media inhibits the colony growth of F. oxysporum. Therefore in-vivo application of fungicide for the control of this disease should be evaluated. Reduction in colony diameter of $F$. oxysporum was observed with the application of used antagonistic fungi. In this connection further studies should be carried out to find out the alternative of fungicide for management of this disease.

\section{Acknowledgment}

This study was funded by the National Science Foundation of China (31660055 and 31660074) and a start-up fund from Hainan University [kyqd1633 and kyqd(zr)1840].

\section{References}

1. Oerke EC. Crop losses to pests. The Journal of Agricultural Science. 2006; 144(1):31-43. https://doi.org/10.1017/ S0021859605005708

2. Introduction. The Identification of Fungi: An Illustrated Introduction with Keys, Glossary, and Guide to Literature. Available from: https://www.amazon.in/IdentificationFungi-Illustrated-Introduction-Literature/dp/0890543364

3. Lucas JA. Fungi, food crops, and biosecurity: Advances and challenges. Advances in Food Security and Sustainability. 2017; 2:1-40. https://doi.org/10.1016/bs.af2s.2017.09.007

4. Yang F, Min W, Wang Q, Wei M, Guo Y, Gao X, Dong, $\mathrm{Lu}$ D. Anastomosis group and pathogenicity of rhizoctonia solani associated with stem canker and black scurf of potato in Heilongjiang Province of China. American Journal of Potato Research. 2017; 94(2):95-104. https://doi. org/10.1007/s12230-016-9535-3

5. Goutam U, Thakur K, Salaria N, Kukreja S. Recent approaches for late blight disease management of potato caused by phytophthora infestans. Fungi and their Role in Sustainable Development: Current Perspectives; 2018. p. 311-25. https://doi.org/10.1007/978-981-13-0393-7_18

6. Mazáková J, Zouhar M, Sedlák P, Zusková E, Ryšánek $\mathrm{P}$, Hausvater E. Sensitivity to fungicides and esential oils in Czech isolates of phytophthora infestans. Scientia Agriculturae Bohemica. 2018; 49(2):69-77. https://doi. org/10.2478/sab-2018-0011 
7. Lin CY, Ni HF, Huang CW. First report of common scab on potato caused by streptomyces europaeiscabiei in Taiwan. Plant Disease. 2018; 102(4):1-818. https://doi.org/10.1094/ PDIS-05-17-0667-PDN

8. Fusarium wilt: A killer disease of lentil. Available from: https://www.intechopen.com/books/fusarium-plant-diseases-pathogen-diversity-genetic-diversity-resistance-andmolecular-markers/fusarium-wilt-a-killer-disease-of-lentil

9. Garibaldi A, Gilardi G, Minerdi D, Gullino ML. First report of leaf spot caused by Phoma exigua on hydrangea macrophylla in Italy. Plant Disease. 2006; 90(8):1-1113. https:// doi.org/10.1094/PD-90-1113B

10. Liu Y, Hu CH, Wang CY, Xiong Y, Li ZK, Xiao C. Occurrence of parthenogenesis in potato tuber moth. Journal of Insect Science. 2018; 18(1):1-14. https://doi.org/10.1093/jisesa/ iey003

11. Hanson L. Sensitivity to Thiabendazole in Fusarium species associated with dry rot of potato. Phytopathology. 1996; 86(4):1-378. https://doi.org/10.1094/Phyto-86-378

12. Fusarium species complex causing Pokkah Boeng in China. Available from: https://www.intechopen.com/ books/fusarium-plant-diseases-pathogen-diversitygenetic-diversity-resistance-and-molecular-markers/ fusarium-species-complex-causing-pokkah-boeng-in-china

13. Maeda K. Studies on Fusarium trichothecene biosynthesis: functional characterization of orthologous pathway genes and development of various types of inhibitors. JSM Mycotoxins. 2018; 68(2):77-82. https://doi.org/10.2520/ myco.68-2-1

14. Ding ZL, Wu JP, Yang CZ, Zhou J, Jiao ZB, Guo FL. First Report of Fusarium meridionale and Fusarium incarnatum Causing Dry Rot of Konjac in China. Plant Disease. 2018; 102(1):1-247. https://doi.org/10.1094/PDIS-06-17-0931-PDN

15. Bammidi K, Dandnayak B. Survey for the incidence of fusarium wilt of coriander in Latur, Osmanabad and Beed Districts of Maharastra. International Journal of Plant and Soil Science. 2018; 23(2):1-5. https://doi. org/10.9734/IJPSS/2018/42513 https://doi.org/10.9734/ IJPSS/2018/43130

16. Dua VK, Rawal S, Singh S, Sharma J. Improving potato cultivation practices: An overview. Burleigh Dodds Series in Agricultural Science; 2018. p. 23-43.

17. Osawa H, Akino S, Araki H, Asano K, Kondo N. Effects of harvest injuries on storage rot of potato tubers infected with Phytophthora infestans. European Journal of Plant Pathology. 2018; 152(2):561-5. https://doi.org/10.1007/ s10658-018-1498-4

18. Struik PC. Understanding ageing processes in seed potatoes. Burleigh Dodds Series in Agricultural Science. 2015; $8: 33-55$.
19. Srivastava S, Kadooka C, Uchida JY. Fusarium species as pathogen on orchids. Microbiological Research. 2018; 207:188-95. https://doi.org/10.1016/j.micres.2017.12.002 PMid:29458853

20. Dubey K, Singh SK. Study cultural, morphological and pathogenic variation among different isolates of Fusarium oxysporum f. sp. lentis. International Journal of Current Microbiology and Applied Sciences. 2018; 7(9):170-5. https://doi.org/10.20546/ijcmas.2018.709.021

21. Pettis GS. Mechanisms of pathogenicity and emergence of new plant-pathogenic species in the genus streptomyces. Virulence Mechanisms of Plant-Pathogenic Bacteria; 2016. p. 445-56. https://doi.org/10.1094/9780890544495.023

22. Hoitink HAJ, Locke JC. An integrated approach to biological control of fusarium species in containerized crops. Fusarium Wilts of Greenhouse Vegetable and Ornamental Crops; 2017. p. 109-15. https://doi. org/10.1094/9780890544822.013

23. Gadgile D. Post-harvest fungal diseases of guava: A brief review. International Journal of Processing and Post Harvest Technology. 2017; 8(1):56-8. https://doi.org/10.15740/ HAS/IJPPHT/8.1/56-58

24. Mejdoub-Trabelsi B, Ben Abdallah RA. Assessment of the antifungal activity of non-pathogenic potato associated fungi toward fusarium species causing tuber dry rot disease. Journal of Plant Pathology and Microbiology. 2016; 7(4):1-114. https://doi.org/10.4172/2157-7471.1000343

25. Hay WT, Fanta GF, Rich JO, Schisler DA, Selling GW. Antifungal activity of a fatty ammonium chloride amylose inclusion complex against Fusarium sambucinum; Control of dry rot on multiple potato varieties. American Journal of Potato Research. 2019; 96(1):79-85. https://doi. org/10.1007/s12230-018-9683-8

26. Fothergill A, Abdelghani A. A review of pesticide residue levels and their related health exposure risks. Food and Environment II. 2013; 170:1-11. https://doi.org/10.2495/ FENV130181

27. Vander Zaag P. Toward sustainable potato production: experience with alternative methods of pest and disease control on a commercial potato farm. American Journal of Potato Research. 2010; 87(5):428-33. https://doi.org/10.1007/ s12230-010-9161-4

28. Peters JC, Lees AK, Cullen DW, Sullivan L, Stroud GP, Cunnington AC. Characterization of Fusarium spp. responsible for causing dry rot of potato in Great Britain. Plant Pathology. 2008; 57(2):262-71. https://doi.org/10.1111/ j.1365-3059.2007.01777.x

29. Choiseul J, Allen L, Carnegie SF. Fungi causing dry tuber rots of seed potatoes in storage in scotland. Potato Research. 2007; 49(4):241-53. https://doi.org/10.1007/s11540-007-9020-y 
30. Dickinson $\mathrm{CH}$, Boardman F. Physiological studies of some fungi isolated from peat. Transactions of the British Mycological Society. 1970; 55(2):293-305. https://doi. org/10.1016/S0007-1536(70)80014-6

31. Pathogenic and morphological variability among Fusarium oxysporum f. sp. ciceri isolates causing wilt in chickpea. Available from: https://www.researchgate.net/ publication/326737978_Pathogenic_and_morphological_variability_among_Fusarium_oxysporum_f_sp_ciceri_isolates_causing_wilt_in_chickpea

32. Bayona LG, Grajales A, Cárdenas ME, Sierra R, Lozano G, Garavito MF, Cepero de García MC, Bernal A, Jiménez P, Restrepo S. Isolation and characterization of two strains of Fusarium oxysporum causing potato dry rot in Solanum tuberosum in Colombia. Revista Iberoamericana de Micología. 2011; 28(4):166-72. https://doi.org/10.1016/j. riam.2011.03.007 PMid:21635960

33. Piwoni A. Pathogenicity of Fusarium avenaceum isolates to tulip leaves assessed on leaf disks. Acta Agrobotanica. 2013; 55(1):265-9. https://doi.org/10.5586/aa.2002.025
34. Yasmin L, Ali M, Khan F. Efficacy of fungicides in controlling fusarium wilt of gladiolus. Bangladesh Journal of Agricultural Research, 2018; 42(4):599-607. https://doi. org/10.3329/bjar.v42i4.35787

35. Theradimani M, Susitha S, Amudha C. Biocontrol of Fusarium Wilt in Tomato caused by Fusarium oxysporum f. sp. lycopersici. International Journal of Current Microbiology and Applied Sciences. 2018; 7(9):420-9. https://doi.org/10.20546/ijcmas.2018.709.052

36. Singh D, Sharma RR. Postharvest diseases of fruits and vegetables and their management. Postharvest Disinfection of Fruits and Vegetables; 2018. p. 1-52. https://doi. org/10.1016/B978-0-12-812698-1.00001-7

37. Spader TB, Venturini TP, Cavalheiro AS, Mahl CD, Mario $\mathrm{DN}$, Lara VM, Alves SH. In vitro interactions between amphotericin $\mathrm{B}$ and other antifungal agents and rifampin against Fusarium spp. Mycoses. 2011; 54(2):131-6. https:// doi.org/10.1111/j.1439-0507.2009.01773.x PMid:19780977 